\title{
Comment on
}

\section{"Tropospheric temperature response to stratospheric ozone recovery in the 21st century" by $\mathrm{Hu}$ et al. (2011)}

\author{
M. Previdi ${ }^{1}$ and L. M. Polvani ${ }^{1,2}$ \\ ${ }^{1}$ Lamont-Doherty Earth Observatory of Columbia University, Palisades, NY, USA \\ ${ }^{2}$ Department of Applied Physics and Applied Mathematics and Department of Earth and Environmental Sciences, \\ Columbia University, New York, NY, USA \\ Correspondence to: M. Previdi (mprevidi@1deo.columbia.edu)
}

Received: 29 November 2011 - Published in Atmos. Chem. Phys. Discuss.: 27 January 2012

Revised: 11 May 2012 - Accepted: 18 May 2012 - Published: 5 June 2012

\begin{abstract}
Stratospheric ozone recovery is expected to figure prominently in twenty-first century climate change. In a recent paper, $\mathrm{Hu}$ et al. (2011) argue that one impact of ozone recovery will be to enhance the warming of the surface-troposphere system produced by increases in wellmixed greenhouse gases. Furthermore, this enhanced warming would be strongest in the Northern Hemisphere, which is surprising since previous studies have consistently shown the effects of stratospheric ozone changes to be most pronounced in the Southern Hemisphere. Hu et al. (2011) base their claims largely on differences in the simulated temperature change between two groups of CMIP3 (Coupled Model Intercomparison Project 3) climate models, one group which included stratospheric ozone recovery in its twenty-first century simulations and a second group which did not. Both groups of models were forced with the same increases in well-mixed greenhouse gases according to the A1B emissions scenario. In the current work, we compare the surface temperature responses of the same two groups of models in a different experiment in which atmospheric $\mathrm{CO}_{2}$ was increased by $1 \%$ per year until doubling. We find remarkably similar differences in the simulated surface temperature change between the two sets of models as $\mathrm{Hu}$ et al. (2011) found for the A1B experiment, suggesting that the enhanced warming which they attribute to stratospheric ozone recovery is actually a reflection of different responses of the two model groups to greenhouse gas forcing.
\end{abstract}

\section{Introduction}

It is now well established that stratospheric ozone depletion has played a dominant role in driving Southern Hemisphere (SH) climate change during the second half of the twentieth century (e.g., see Polvani et al., 2011b and references therein). Similarly, ozone recovery during the first half of the twenty-first century is expected to have important implications for SH climate (Polvani et al., 2011a). Stratospheric ozone changes significantly alter the radiative heating in the polar lower stratosphere with resulting impacts on stratospheric temperatures. Model simulations suggest that these temperature impacts are on the order of $10 \mathrm{~K}$ in the Antarctic lower stratosphere during austral summer (DecemberFebruary, DJF; Polvani et al., 2011a,b). Heating or cooling of the polar lower stratosphere alters the meridional temperature gradient at tropopause levels, which affects the position of the tropospheric westerly jet and descending branch of the tropical Hadley circulation. In the case of ozone depletion, the tropospheric jet shifts poleward, which is often referred to as a positive trend in the Southern Annular Mode (SAM). Ozone recovery has the opposite effect on the tropospheric circulation, favoring an equatorward shift of the jet and Hadley cell, and thus a negative SAM trend. Importantly, this effect of ozone recovery is expected to largely cancel the effect of increasing greenhouse gases (GHGs) during the next $50 \mathrm{yr}$, resulting in minimal forced circulation changes in the SH during DJF (Shindell and Schmidt, 2004; Son et al., 2010; Polvani et al., 2011a; McLandress et al., 2011). 
While the response of stratospheric temperatures to ozone depletion and recovery is unambiguous, the response of tropospheric and surface temperatures is less clear. Some amount of tropospheric temperature adjustment is necessary in order to maintain thermal wind balance as the latitudinal position of the tropospheric jet shifts in association with ozone changes. For example, the poleward shift of the jet (positive SAM trend) due to ozone depletion is expected to be associated with an enhanced tropospheric temperature gradient between the Antarctic and midlatitude SH. Previous studies of SAM variability have shown that this enhanced temperature gradient is maintained by anomalous vertical motion which adiabatically cools the polar troposphere and warms the midlatitude troposphere (Thompson et al., 2003).

Near the surface, changes in the SAM are expected to be associated with regional warming and cooling. For instance, Thompson et al. (2011) suggest that about half of the surface warming over the Antarctic Peninsula and nearly all of the surface cooling over east Antarctica which were observed during DJF from the 1970s to the early 2000s can be explained by the positive trend in the SAM during this period, which was primarily driven by stratospheric ozone depletion. However, while ozone changes may affect tropospheric and surface temperatures regionally through changes in circulation, it is not clear that there should be an impact on larger spatial scales.

In a recent study, Hu et al. (2011) (hereafter, H11) conclude that stratospheric ozone recovery during 2001-2050 will enhance global and annual mean warming in the upper troposphere and at the surface by $\sim 0.41 \mathrm{~K}$ and $0.16 \mathrm{~K}$, respectively. Surprisingly, this enhanced warming is argued to be greatest in the Northern Hemisphere (NH), despite the fact that SH ozone changes are anticipated to be much larger. H11 suggest that ozone recovery will enhance surface warming most strongly in the wintertime Arctic, another unexpected result since the maximum increase in ozone occurs in the spring. $\mathrm{H} 11$ base their conclusions primarily on differences in the climate response between two groups of CMIP3 models, one group which included stratospheric ozone recovery in its 21st century simulations and a second group which did not. Both groups of models included the same increases in well-mixed GHGs based on the A1B emissions scenario. McLandress et al. (2012) suggest that differences in the response to GHG forcing between these two sets of models could account for the simulated differences in tropospheric and surface temperatures noted by H11. Here, we present evidence that this is indeed the case, and that the temperature differences discussed by $\mathrm{H} 11$ are therefore not due to stratospheric ozone recovery.

\section{Methodology}

We consider the same two groups of CMIP3 coupled atmosphere-ocean models analyzed by H11 (see
Table 1. Globally averaged differences in annual mean, DJF and JJA surface air temperature (SAT) trends (in K per decade) between GROUP1 and GROUP2 models in the A1B and $1 \% \mathrm{yr}^{-1} \mathrm{CO}_{2}$ experiments. Numbers in parentheses are the trend differences averaged over the Arctic region $\left(60^{\circ} \mathrm{N}-90^{\circ} \mathrm{N}\right)$.

\begin{tabular}{lcc}
\hline & A1B experiment & $1 \% \mathrm{yr}^{-1} \mathrm{CO}_{2}$ experiment \\
\hline Annual mean & $0.05(0.14)$ & $0.06(0.19)$ \\
DJF & $0.05(0.21)$ & $0.07(0.26)$ \\
JJA & $0.05(0.09)$ & $0.06(0.10)$ \\
\hline
\end{tabular}

their Table 1). The first group (hereafter, GROUP1), which included stratospheric ozone recovery in its 21st century simulations, includes the following models: CSIRO MK3.5, GFDL CM2.0, GFDL CM2.1, INGV SXG, MIROC3.2 hires, MIROC3.2 medres, MPI ECHAM5/MPIOM, NCAR CCSM3.0, UKMO HadCM3, and UKMO HadGEM1. The second group (GROUP2), which did not account for ozone recovery, includes GISS EH, GISS ER, BCCR BCM2.0, CCCma CGCM3.1 T47, CCCma CGCM3.1 T63, CNRM CM3, GISS AOM, IAP FGOALS-g1.0, INM CM3.0, IPSL CM4, and MRI CGCM2.3.2. We evaluate simulated changes in monthly surface air temperature (SAT) from both groups of models, for two different experiments: (1) the A1B experiment considered by $\mathrm{H} 11$, and (2) an experiment in which atmospheric $\mathrm{CO}_{2}$ is increased by $1 \%$ per year until it doubles after $\sim 70 \mathrm{yr}$. To be clear, in the $1 \% \mathrm{yr}^{-1}$ $\mathrm{CO}_{2}$ experiment all models in GROUP1 and GROUP2 have identical forcing, whereas in the A1B experiment the stratospheric ozone forcing differs between GROUP1 and GROUP2 (being zero in the latter). Note that in the A1B experiment, other forcings besides stratospheric ozone may also be different in GROUP1 and GROUP2 models (see, e.g., Table 10.1 in Meehl et al., 2007).

We compute linear trends in SAT for all available ensemble members from each model. The ensemble mean trend for each model is then calculated, followed by the multimodel mean trends for GROUP1 and GROUP2. Following H11, SAT trends are computed over the period 2001-2050 for the A1B experiment. For the $1 \% \mathrm{yr}^{-1} \mathrm{CO}_{2}$ experiment, trends are computed over years $1-70$.

\section{Results}

Figure 1 and Table 1 show differences in annual, DJF and JJA SAT trends (in K per decade) between GROUP1 and GROUP2. Trend differences for the A1B experiment analyzed by $\mathrm{H} 11$ are plotted on the left in Fig. 1, while trend differences for the $1 \% \mathrm{yr}^{-1} \mathrm{CO}_{2}$ experiment are on the right. As noted by H11, GROUP1 models simulate greater surface warming during 2001-2050 than GROUP2 models (Fig. 1a), with this enhanced warming being most pronounced in 

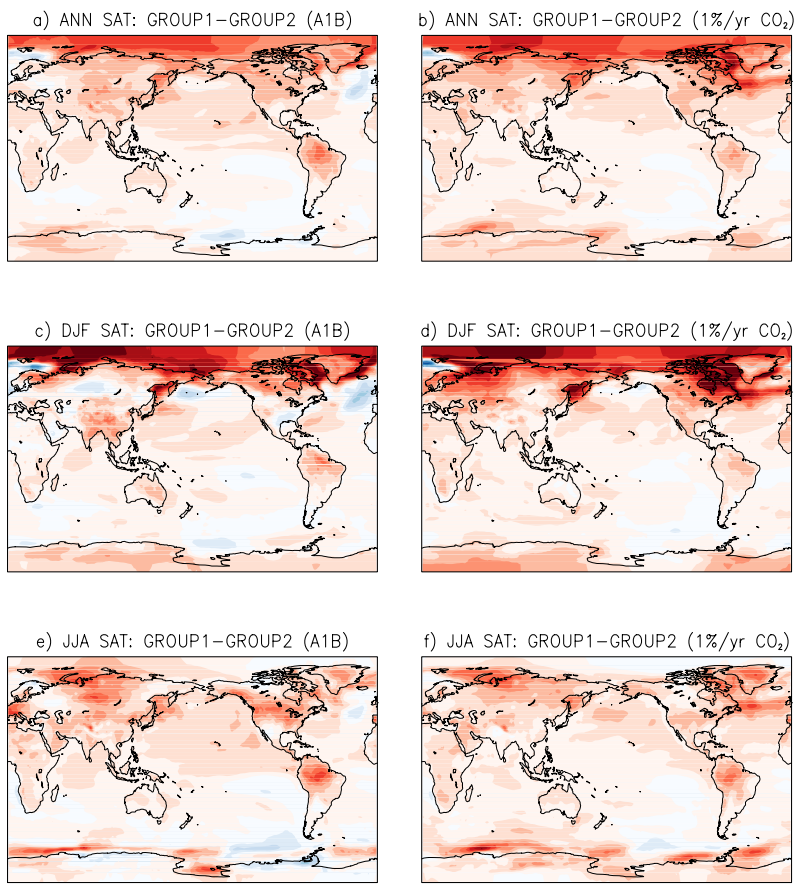

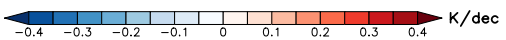

Fig. 1. Differences in annual mean (ANN), DJF and JJA surface air temperature (SAT) trends (in K per decade) between two groups of CMIP3 climate models. Trend differences for 2001-2050 in the A1B experiment are shown on the left, while differences for years $1-70$ in the $1 \% \mathrm{yr}^{-1} \mathrm{CO}_{2}$ experiment are on the right. Models in GROUP1 included stratospheric ozone recovery in the A1B experiment and GROUP2 models did not.

the Arctic during DJF (Fig. 1c). In the global and annual mean, the anomalous (i.e., GROUP1 minus GROUP2) surface warming in the A1B experiment is $0.05 \mathrm{~K} /$ decade (or $0.25 \mathrm{~K}$ per $50 \mathrm{yr}$ ). This is also the magnitude of the global mean warming anomaly for DJF and JJA in the A1B experiment, although the enhanced warming that occurs over the Arctic in DJF and the annual mean is diminished in JJA (see also Table 1). The global and annual mean SAT trend difference of $0.25 \mathrm{~K}$ per $50 \mathrm{yr}$ reported here is somewhat larger than the value of $0.16 \mathrm{~K}$ per $50 \mathrm{yr}$ reported by H11. However, $\mathrm{H} 11$ also state that the corresponding trend differences for the $\mathrm{NH}$ and SH separately are $0.35 \mathrm{~K}$ per $50 \mathrm{yr}$ and $0.11 \mathrm{~K}$ per $50 \mathrm{yr}$, respectively. The average of these two values is $0.23 \mathrm{~K}$ per $50 \mathrm{yr}$, which is much closer to the global mean trend difference that we have computed.

As discussed above, H11 attribute the enhanced surface warming in the GROUP1 models to the effects of stratospheric ozone recovery. It is clear from the right column of Fig. 1, however, that the same SAT trend differences between GROUP1 and GROUP2 exist in the $1 \% \mathrm{yr}^{-1} \mathrm{CO}_{2}$ experiment, where stratospheric ozone changes are not included. The similarity of spatial patterns compared to the A1B experiment is striking, with, e.g., the largest SAT trend differences in both experiments occurring over the Arctic Ocean in DJF (Fig. 1c and d). We find these trend differences to be associated with greater Arctic sea ice loss in the GROUP1 models relative to the GROUP2 models (not shown). The global mean warming anomalies for the $1 \% \mathrm{yr}^{-1} \mathrm{CO}_{2}$ experiment are also very similar to those reported earlier for A1B, being $0.06,0.07$ and $0.06 \mathrm{~K} /$ decade for the annual mean, DJF and JJA, respectively.

The results in Fig. 1 and Table 1, therefore, provide strong evidence that the enhanced surface (and by implication the tropospheric) warming in GROUP1 compared to GROUP2, which $\mathrm{H} 11$ attributed to stratospheric ozone recovery, instead reflects differences in the response to GHG forcing between the two sets of models.

\section{Conclusions}

Stratospheric ozone changes impact climate in a number of ways, as discussed briefly in the introduction and documented extensively elsewhere. Recently, $\mathrm{Hu}$ et al. (2011) claimed a previously unreported effect of ozone changes. They argued that ozone recovery in the 21 st century will act to amplify warming in the troposphere and at the surface, with the largest impacts felt in the NH. H11 base this conclusion primarily on differences in the simulated temperature change between two groups of CMIP3 climate models, one group which included stratospheric ozone recovery in its 21 st century simulations and a second group which did not. We have shown here, however, that differences in future warming between these two groups of models can be largely attributed to differences in their response to GHG forcing, rather than to any effect of ozone recovery. In fact, ozone recovery was found to produce a slight cooling of the $\mathrm{NH}$ troposphere in a coupled chemistry-climate model (McLandress et al., 2012), in contrast to the H11 result. It should be pointed out, though, that this cooling is based on only a single model, and it will be necessary to examine multiple models in order to robustly establish the tropospheric temperature effects of ozone recovery.

The current work thus serves to highlight the potential difficulties of employing the multimodel difference approach of H11 to infer the effects of stratospheric ozone changes. While this approach may be adequate for cases where the ozone signal is large (e.g., for SH circulation changes in DJF; see Son et al., 2008), in other cases differences in simulated climate change between models are likely to arise due to factors other than ozone. Our results demonstrate that the multimodel difference approach of $\mathrm{H} 11$ is not suitable for inferring the effects of stratospheric ozone recovery on surfacetroposphere temperatures. We therefore contend that the H11 claim that ozone recovery will enhance global surface warming in the twenty-first century is likely to be erroneous. 
Acknowledgements. We gratefully acknowledge support from the NSF Antarctic Sciences program, ANT 09-44063. We also thank four anonymous reviewers whose comments helped strengthen the manuscript.

Edited by: M. Dameri

\section{References}

$\mathrm{Hu}$, Y., Xia, Y., and Fu, Q.: Tropospheric temperature response to stratospheric ozone recovery in the 21 st century, Atmos. Chem. Phys., 11, 7687-7699, doi:10.5194/acp-11-7687-2011, 2011.

McLandress, C., Shepherd, T. G., Scinocca, J. F., Plummer, D. A., Sigmond, M., Jonsson, A. I., and Reader, M. C.: Separating the dynamical effects of climate change and ozone depletion, Part II: Southern Hemisphere troposphere, J. Climate, 24, 1850-1868, 2011.

McLandress, C., Perlwitz, J., and Shepherd, T. G.: Comment on "Tropospheric temperature response to stratospheric ozone recovery in the 21 st century" by Hu et al. (2011), Atmos. Chem. Phys., 12, 2533-2540, doi:10.5194/acp-12-2533-2012, 2012.

Meehl, G. A., Stocker, T. F., Collins, W. D., Friedlingstein, P., Gaye, A. T., Gregory, J. M., Kitoh, A., Knutti, R., Murphy, J. M., Noda, A., Raper, S. C. B., Watterson, I. G., Weaver, A. J., and Zhao, Z.C.: Global Climate Projections, in: Climate Change 2007: The Physical Science Basis. Contribution of Working Group I to the Fourth Assessment Report of the Intergovernmental Panel on Climate Change, edited by: Solomon, S., Qin, D., Manning, M., Chen, Z., Marquis, M., Averyt, K. B., Tignor, M., and Miller, H. L., Cambridge University Press, Cambridge, UK and New York, NY, USA, 2007.
Polvani, L. M., Previdi, M., and Deser, C.: Large cancellation, due to ozone recovery, of future Southern Hemisphere atmospheric circulation trends, Geophys. Res. Lett., 38, L04707, doi:10.1029/2011GL046712, 2011a.

Polvani, L. M., Waugh, D. W., Correa, G. J. P., and Son, S.-W.: Stratospheric ozone depletion: the main driver of 20th century atmospheric circulation changes in the Southern Hemisphere, J. Climate, 24, 795-812, doi:10.1175/2010JCLI3772.1, $2011 \mathrm{~b}$.

Shindell, D. T. and Schmidt, G. A.: Southern Hemisphere climate response to ozone changes and greenhouse gas increases, Geophys. Res. Lett., 31, L18209, doi:10.1029/2004GL020724, 2004.

Son, S.-W., Polvani, L. M., Waugh, D. W., Akiyoshi, H., Garcia, R., Kinnison, D., Pawson, S., Rozanov, E., Shepherd, T. G., and Shibata, K.: The impact of stratospheric ozone recovery on the Southern Hemisphere westerly jet, Science, 320, 1486-1489, 2008.

Son, S.-W., Gerber, E. P., Perlwitz, J., Polvani, L. M., Gillett, N., Seo, K.-H., and SPARC/CCMVal co-authors: Impact of stratospheric ozone on Southern Hemisphere circulation change: a multimodel assessment, J. Geophys. Res., 115, D00M07, doi:10.1029/2010JD014271, 2010.

Thompson, D. W. J., Lee, S., and Baldwin, M. P.: Atmospheric processes governing the Northern Hemisphere Annular Mode/North Atlantic Oscillation, in: The North Atlantic Oscillation: Climatic Significance and Environmental Impact, edited by: Hurrell, J. W., Kushnir, Y., Ottersen, G., and Visbeck, M., AGU Geophysical Monograph 134, American Geophysical Union, Washington, DC, 81-112, 2003.

Thompson, D. W. J., Solomon, S., Kushner, P. J., England, M. H., Grise, K. M., and Karoly, D. J.: Signatures of the Antarctic ozone hole in Southern Hemisphere surface climate change, Nat. Geosci., 4, 741-749, 2011. 